\title{
Synthesis and Molecular Structure of Zwitterionic Complexes of Phenothiazine-5-oxide Derivatives Coordinated with Cobalt(II) and Copper(II) Ions
}

\author{
Hiroko Nakagawa, Junko Chikuma, Chun-Guang Li, Koh-ichi Yamada, and \\ Hiroshi Kaẉazura* \\ Faculty of Pharmaceutical Sciences, Josai University, Sakado, Saitama 350-02, Japan. Received March 4, 1993
}

The synthesis and characterization of $\mathrm{Co}(\mathrm{II}) \mathrm{Cl}_{2}$ and $\mathrm{Cu}(\mathrm{II}) \mathrm{Cl}_{2}$ complexes with 2-chloro-10-(3-dimethylaminopropyl)phenothiazine-5-oxide hydrochloride $(\mathrm{cpz}(\mathrm{O}) \mathrm{HCl})$ and three related compounds are described. The crystal structures of the complexes $\left[\mathrm{CoCl}_{3} \mathrm{cpz}(\mathrm{O}) \mathrm{H}\right](1)$ and $\left[\mathrm{CuCl}_{3} \mathrm{cpz}(\mathrm{O}) \mathrm{H}\right](2)$ were determined by single-crystal X-ray diffraction analyses. 1 crystallizes in the monoclinic space group $P 2_{1} / c$ with $a=8.150(1), b=17.763(2), c=14.630(2) \AA$, $\beta=103.93(1)^{\circ}, V=2055.8(3) \AA^{3}$, and $Z=4$. 2 crystallizes in the monoclinic space group $P 2_{1} / c$ with $a=8.141(1)$, $b=17.175(4), c=14.810(3) \AA, \beta=103.27(1)^{\circ}, V=2015.5(7) \AA^{3}$, and $Z=4$. The metal atoms in both complexes are coordinated in a tetrahedral geometry and the two complexes are arranged in a head-to-tail manner to form a dimer.

Keywords chlorpromazine-5-oxide; phenothiazine-5-oxide derivative; zwitterionic complex; cobalt(II) complex; copper(II) complex; X-ray analysis

Since the reports that administration of 2-chloro-10-(3dimethylaminopropyl)phenothiazine (chlorpromazine, $\mathrm{cpz}$ ) to rats causes a change in copper levels in brain tissues, ${ }^{1)}$ much effort has been devoted to investigating the interaction between $\mathrm{cpz}$ and various metal ions in order to understand biochemical mechanisms by which the drug acts. However, no definite evidence for the interaction (such as isolation of the coordination compounds) has been produced in any reports which generally showed only the spectroscopic behavior of solutions containing $\mathrm{cpz}$ and metal ions, ${ }^{2)}$ except for the structural analyses of the heavy metal (Pt and $\mathrm{Pd}$ ) complexes of promethazine (pmt). ${ }^{3)}$

In the course of our studies of the interaction between $\mathrm{cpz}$ or related phenothiazine derivatives and transition metal ions, we found that chlorpromazine-5-oxide hydrochloride $[\operatorname{cpz}(\mathrm{O}) \mathrm{HCl}]$, one of the major metabolites of $\mathrm{cpz}^{4}{ }^{4}$ reacted with $\mathrm{Co}(\mathrm{II}) \mathrm{Cl}_{2}$ and $\mathrm{Cu}(\mathrm{II}) \mathrm{Cl}_{2}$ to give zwitterionic coordination complexes with the negative charge around the metal center and the positive one on the ligand. Although there have not been many studies on metalzwitterionic complexes, interesting properties such as their catalytic action in the synthesis of organic compounds ${ }^{5)}$ and their use as intermediates in catalytic reactions $^{6)}$ have been described. Recently, the crystal structures of dicopper(II) and tricopper(II) zwitterionic complexes with amino alcohol ligands have been reported. ${ }^{7}$
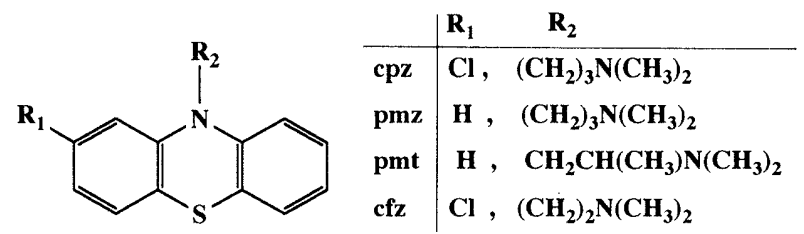

\section{Experimental}

Chlorpromazine hydrochloride $(\mathrm{cpz} \cdot \mathrm{HCl})$ (Aldrich) was recrystallized from chloroform acetone. Promazine hydrochloride ( $\mathrm{pmz} \cdot \mathrm{HCl})($ Sigma) and promethazine hydrochloride $(\mathrm{pmt} \cdot \mathrm{HCl})$ (Wako) were used without further purification. Chlorfenethazine hydrochloride $(\mathrm{cfz} \cdot \mathrm{HCl})$ was prepared by coupling $N, N$-dimethyl-2-chloroethylamine with 2-chlorophenothiazine in the presence of sodium hydride in dry xylene ${ }^{8)}$ followed by recrystallization from methanol-benzene. Anal. Calcd for $\mathrm{C}_{16} \mathrm{H}_{18} \mathrm{Cl}_{2}$ $\mathrm{N}_{2} \mathrm{~S}$ : C, 56.31; H, 5.32; N, 8.21. Found: C, 56.22; H, 5.17; N, 7.92.
Chlorpromazine-5-oxide Hydrochloride Dihydrate $\left(\mathrm{cpz}(\mathrm{O}) \mathrm{HCl} \cdot \mathbf{2} \mathrm{H}_{2} \mathrm{O}\right)$ To $80 \mathrm{ml}$ of an ethanolic solution of $\mathrm{cpz} \cdot \mathrm{HCl}(20 \mathrm{~g}, 56.3 \mathrm{mmol}), 5.74 \mathrm{ml}$ $35 \%$ aqueous hydrogen peroxide $(59.1 \mathrm{mmol})$ was added at room temperature with stirring and the solution allowed to stand over night. Then, the reaction mixture was refluxed for 2 more hours and the solvent evaporated under reduced pressure. ${ }^{9)}$ The residue was recrystallized from isopropyl alcohol to give white crystals $(21.9 \mathrm{~g}, 95.5 \%)$. Anal. Calcd for $\mathrm{C}_{17} \mathrm{H}_{24} \mathrm{Cl}_{2} \mathrm{~N}_{2} \mathrm{O}_{3} \mathrm{~S}: \mathrm{C}, 50.12 ; \mathrm{H}, 5.94 ; \mathrm{N}, 6.88$. Found; C, 50.28; H, 5.55; $\mathrm{N}, 6.81$.

Promazine-5-oxide hydrochloride 1.5 hydrate $\left(\mathrm{pmz}(\mathrm{O}) \mathrm{HCl} \cdot 1.5 \mathrm{H}_{2} \mathrm{O}\right.$, Anal. Calcd for $\mathrm{C}_{17} \mathrm{H}_{24} \mathrm{ClN}_{2} \mathrm{O}_{2.5} \mathrm{~S}: \mathrm{C}, 56.11 ; \mathrm{H}, 6.65 ; \mathrm{N}, 7.70$. Found: C, $56.63 ; \mathrm{H}, 6.28 ; \mathrm{N}, 7.70)$, promethazine-5-oxide hydrochloride $(\mathrm{pmt}(\mathrm{O}) \mathrm{HCl}$, Anal. Calcd for $\mathrm{C}_{17} \mathrm{H}_{21} \mathrm{CIN}_{2} \mathrm{OS}$ : C, 60.61; H, 6.28; N, 8.32. Found: C, $61.02 ; \mathrm{H}, 6.28 ; \mathrm{N}, 8.14)$, and chlorfenethazine-5-oxide hydrochloride 0.5 hydrate $\left(\mathrm{cfz}(\mathrm{O}) \mathrm{HCl} \cdot 0.5 \mathrm{H}_{2} \mathrm{O}\right.$, Anal. Calcd for $\mathrm{C}_{16} \mathrm{H}_{19} \mathrm{Cl}_{2} \mathrm{~N}_{2} \mathrm{O}_{1.5} \mathrm{~S}$ : $\mathrm{C}, 52.46 ; \mathrm{H}, 5.23$; N, 7.65. Found: C, 53.01; H, 5.02; N, 7.62) were synthesized by a similar procedure.

$\left[\mathrm{CoCl}_{3} \mathbf{c p z}(\mathrm{O}) \mathrm{H}\right]$ (1) An ethanolic solution containing $\mathrm{cpz}(\mathrm{O}) \mathrm{HCl}$. $2 \mathrm{H}_{2} \mathrm{O}(0.407 \mathrm{~g}, 1 \mathrm{mmol})$ and $\mathrm{CoCl}_{2} \cdot 6 \mathrm{H}_{2} \mathrm{O}(0.238 \mathrm{~g}, 1 \mathrm{mmol})$ was allowed to stand for several days. Small blue crystals of $\left[\mathrm{CoCl}_{3} \mathrm{cpz}(\mathrm{O}) \mathrm{H}\right]$ were gradually deposited and then collected $(0.450 \mathrm{~g}, 89.8 \%)$. Other complexes of the same coordination type, $\left[\mathrm{CoCl}_{3} \mathrm{pmz}(\mathrm{O}) \mathrm{H}\right],\left[\mathrm{CoCl}_{3} \operatorname{pmt}(\mathrm{O}) \mathrm{H}\right]$, $\left[\mathrm{CoCl}_{3} \mathrm{cfz}(\mathrm{O}) \mathrm{H}\right]$, and $\left[\mathrm{CuCl}_{3} \operatorname{cpz}(\mathrm{O}) \mathrm{H}\right](2)$, were prepared by a similar procedure.

Measurements Infrared (IR) spectra were obtained on a JASCO IR810 Infrared Spectrophotometer using $\mathrm{KBr}$ disks. Magnetic susceptibilities were measured on a Shimazu Torsion Magnetometer MB-100, using $\left(\mathrm{NH}_{4}\right)_{2} \mathrm{Fe}\left(\mathrm{SO}_{4}\right)_{2}$ as a standard.

X-Ray Crystal Structure Analyses Metal complexes 1 and $\mathbf{2}$ were slowly crystallized from ethanol to give blue columns for $\mathbf{1}$ and dark orange needles for $\mathbf{2}$. Both crystals were mounted on glass capillaries and sealed with epoxy glue. Intensity data were collected on a Rigaku AFC-5 four-circle diffractometer in a $\theta-2 \theta$ scan mode (scan rate for $\theta=4^{\circ} / \mathrm{min}$ ) using graphite-monochromatized $\operatorname{MoK}_{\alpha}$ radiation $(\lambda=0.70926 \AA)$. All the calculations were carried out on a FACOM M770/8 computer at this university. The densities of the crystals were measured by flotation. All the data were corrected for Lorentz and polarization effects, but not for absorption.

A total of 4988 reflections in the range of $2 \theta<55^{\circ}(h: 0 \rightarrow 10, k: 0 \rightarrow 23$, $l:-17 \rightarrow 18)$, and 3744 in the range of $2 \theta<65^{\circ}(h: 0 \rightarrow 12, k: 0 \rightarrow 26, l$ : $-22 \rightarrow 22$ ) were collected for 1 and 2 , respectively. During the data collection, three standard reflections were monitored every 150 reflections for 1 and every 200 reflections for 2 ; they showed no significant variations in their intensitities $(<0.6 \%)$. The unit-cell parameters were refined from the least-squares fits of 26 reflections $\left(24<2 \theta<29^{\circ}\right)$ for 1 and 24 reflections $\left(21<2 \theta<30^{\circ}\right)$ for 2 . Finally, 2582 reflections having $F_{\mathrm{O}}>4 \sigma\left(F_{\mathrm{o}}\right)$ for 1 and 2252 reflections having $F_{\mathrm{O}}>6 \sigma\left(F_{\mathrm{O}}\right)$ for 2 were used for the structure determinations. The structures were solved by the direct method using the SHELX86 program, ${ }^{10)}$ then refined by the block-diagonal least-squares 
TABLE I. Crystal and Intensity Data for $\left[\mathrm{CoCl}_{3} \mathrm{cpz}(\mathrm{O}) \mathrm{H}\right]$ and $\left[\mathrm{CuCl}_{3}{ }^{-}\right.$ $\operatorname{cpz}(\mathrm{O}) \mathrm{H}]$

\begin{tabular}{|c|c|c|}
\hline & {$\left[\mathrm{CoCl}_{3} \mathrm{cpz}(\mathrm{O}) \mathrm{H}\right]$} & {$\left[\mathrm{CuCl}_{3} \operatorname{cpz}(\mathrm{O}) \mathrm{H}\right]$} \\
\hline Formula & $\mathrm{C}_{17} \mathrm{H}_{20} \mathrm{Cl}_{4} \mathrm{CoN}_{2} \mathrm{OS}$ & $\mathrm{C}_{17} \mathrm{H}_{20} \mathrm{Cl}_{4} \mathrm{CuN}_{2} \mathrm{OS}$ \\
\hline Formula weight & 501.172 & 505.76 \\
\hline \multicolumn{3}{|l|}{ Cell constants } \\
\hline$a(\AA)$ & $8.150(1)$ & $8.141(1)$ \\
\hline$b(\AA)$ & $17.763(2)$ & $17.175(4)$ \\
\hline$c(\AA)$ & $14.630(2)$ & $14.810(3)$ \\
\hline$\beta\left(^{\circ}\right)$ & $103.93(1)$ & $103.27(1)$ \\
\hline$V\left(\AA^{3}\right)$ & $2055.8(3)$ & $2015.5(7)$ \\
\hline$D_{\mathrm{c}}\left(\mathrm{g} \mathrm{cm}^{-3}\right)$ & 1.626 & 1.667 \\
\hline$D_{\mathrm{m}}\left(\mathrm{g} \mathrm{cm}^{-3}\right)$ & $1.60(2)$ & $1.67(1)$ \\
\hline$Z$ & 4 & 4 \\
\hline System & Monoclinic & Monoclinic \\
\hline Space group & $P 2_{1} / c$ & $P 2_{1} / c$ \\
\hline$\mu\left(\mathrm{MoK} K_{\alpha}\right)\left(\mathrm{cm}^{-1}\right)$ & 14.7 & 17.3 \\
\hline Independent reflections & $2582\left(F_{\mathrm{O}}>4 \sigma\left(F_{\mathrm{O}}\right)\right)$ & $2252\left(F_{\mathrm{O}}>6 \sigma\left(F_{\mathrm{O}}\right)\right)$ \\
\hline Crystal dimensions $\left(\mathrm{mm}^{3}\right)$ & $0.3 \times 0.4 \times 0.5$ & $0.1 \times 0.2 \times 0.6$ \\
\hline$R\left(R_{w}\right)$ & $0.079(0.060)$ & $0.062(0.072)$ \\
\hline$F(000)$ & 1020 & 1028 \\
\hline
\end{tabular}

TABLE II. Positional Parameters $\left(\times 10^{4}\right)$ and Equivalent Isotropic Temperature Factors for Non-hydrogen Atoms in $\left[\mathrm{CoCl}_{3} \mathrm{cpz}(\mathrm{O}) \mathrm{H}\right]$

\begin{tabular}{|c|c|c|c|c|}
\hline & $x$ & $y$ & $z$ & $B_{\text {eq }}\left(\AA^{2}\right)$ \\
\hline Co & $1568(1)$ & $3470(1)$ & $2896(1)$ & $2.91(0.03)$ \\
\hline $\mathrm{Cl}(1)$ & $-957(1)$ & 2861 (1) & $2426(1)$ & $4.61(0.07)$ \\
\hline $\mathrm{Cl}(2)$ & 3807 (2) & 2733 (1) & $3463(2)$ & $6.33(0.10)$ \\
\hline $\mathrm{Cl}(3)$ & $1302(2)$ & 4424 (1) & $3856(2)$ & $6.48(0.09)$ \\
\hline $\mathrm{Cl}(4)$ & $5184(2)$ & $6961(2)$ & $3984(2)$ & $4.91(0.10)$ \\
\hline $\mathrm{Cl}\left(4^{\prime}\right)$ & $1142(9)$ & $5068(6)$ & $-2405(7)$ & $5.20(0.37)$ \\
\hline $\mathrm{S}$ & 3715 (1) & 4079 (1) & $1560(1)$ & $2.79(0.06)$ \\
\hline $\mathrm{O}$ & $1963(3)$ & $3823(3)$ & $1671(3)$ & $3.01(0.15)$ \\
\hline$N(1)$ & $2306(3)$ & $5649(3)$ & 949 (4) & $2.40(0.17)$ \\
\hline $\mathrm{N}(2)$ & 977 (4) & $8163(3)$ & $-590(4)$ & $3.16(0.19)$ \\
\hline $\mathrm{C}(1)$ & $2446(3)$ & $5158(4)$ & $234(4)$ & $2.25(0.20)$ \\
\hline $\mathrm{C}(2)$ & $1769(4)$ & $5325(4)$ & $-715(5)$ & $2.97(0.23)$ \\
\hline $\mathrm{C}(3)$ & $1998(4)$ & 4857 (4) & $-1412(5)$ & $3.15(0.22)$ \\
\hline $\mathrm{C}(4)$ & $2860(4)$ & $4182(4)$ & $-1229(5)$ & $3.20(0.23)$ \\
\hline $\mathrm{C}(5)$ & $3478(4)$ & 3989 (4) & $-299(5)$ & $3.06(0.23)$ \\
\hline $\mathrm{C}(6)$ & $3270(4)$ & $4462(4)$ & $433(5)$ & $2.57(0.21)$ \\
\hline $\mathrm{C}(7)$ & $3341(4)$ & $5602(4)$ & $1852(5)$ & $2.60(0.22)$ \\
\hline $\mathrm{C}(8)$ & $3670(4)$ & $6227(4)$ & $2452(5)$ & $2.87(0.22)$ \\
\hline $\mathrm{C}(9)$ & 4759 (4) & $6157(4)$ & $3320(5)$ & $3.54(0.24)$ \\
\hline$C(10)$ & $5559(5)$ & $5489(5)$ & $3648(5)$ & $4.07(0.27)$ \\
\hline $\mathrm{C}(11)$ & $5238(4)$ & $4867(4)$ & $3065(5)$ & $3.43(0.25)$ \\
\hline $\mathrm{C}(12)$ & $4158(4)$ & $4914(4)$ & $2182(5)$ & $2.81(0.22)$ \\
\hline $\mathrm{C}(13)$ & $1126(4)$ & $6295(4)$ & $713(5)$ & $2.66(0.21)$ \\
\hline$C(14)$ & $1858(4)$ & $6980(4)$ & 317 (4) & $2.56(0.22)$ \\
\hline $\mathrm{C}(15)$ & 408 (4) & 7522 (4) & $-79(5)$ & $2.72(0.23)$ \\
\hline$C(16)$ & $2119(5)$ & $8674(4)$ & $64(5)$ & $3.88(0.27)$ \\
\hline $\mathrm{C}(17)$ & $-504(6)$ & $8597(5)$ & $-1132(6)$ & $4.96(0.31)$ \\
\hline
\end{tabular}

approximations using the UNICSIII program ${ }^{11)}$; the ORTEP program ${ }^{12}$ ) was used to obtain the structure diagrams. The ten hydrogen atoms of 1 and the five hydrogen atoms of 2 were located from the difference Fourier syntheses, and all the other hydrogens were located by calculation. Complex neutral-atom scattering factors were taken from the International Tables for X-Ray Crystallography. ${ }^{13)}$ The final $R$ values converged to 0.079 , and 0.062 , and the $R_{w}$ values to $0.060\left(w=1 /\left\{\sigma^{2}+0.02 \times F_{\mathrm{O}}^{2}\right\}\right)$ and $0.072(w=1)$ for 1 and 2 , respectively. The $(\Delta / \sigma)_{\max }$ values were 0.013 and 0.16 , the maximum heights in the final difference Fourier synthesis were 0.80 and $0.86 e \AA^{-3}$, and the $S$ values were 1.48 and 3.18 for 1 and 2 , respectively.

The crystal and intensity data for $\mathbf{1}$ and $\mathbf{2}$ are shown in Table I. The final atomic coordinates and the thermal parameters for $\mathbf{1}$ and $\mathbf{2}$ are listed in Tables II and III, respectively.
TABle III. Positional Parameters $\left(\times 10^{4}\right)$ and Equivalent Isotropic Temperature Factors for Non-hydrogen Atoms in $\left[\mathrm{CuCl}_{3} \mathrm{cpz}(\mathrm{O}) \mathrm{H}\right]$

\begin{tabular}{|c|c|c|c|c|}
\hline & $x$ & $y$ & $z$ & $B_{\text {eq }}\left(\AA^{2}\right)$ \\
\hline $\mathrm{Cu}$ & $1533(2)$ & $1538(1)$ & 2891 (1) & $2.84(0.03)$ \\
\hline $\mathrm{Cl}(1)$ & $-1104(3)$ & $2014(2)$ & $2381(2)$ & $4.15(0.08)$ \\
\hline $\mathrm{Cl}(2)$ & $3942(4)$ & $2135(2)$ & $3452(2)$ & $5.17(0.10)$ \\
\hline $\mathrm{Cl}(3)$ & $1277(5)$ & $705(2)$ & $3974(2)$ & $6.10(0.12)$ \\
\hline $\mathrm{Cl}(4)$ & $5264(5)$ & $-1959(2)$ & $3918(2)$ & $4.31(0.11)$ \\
\hline $\mathrm{Cl}\left(4^{\prime}\right)$ & $1074(20)$ & $-24(9)$ & $-2387(9)$ & $4.55(0.42)$ \\
\hline $\mathrm{S}$ & $3686(3)$ & 1009 (1) & $1522(2)$ & $2.41(0.06)$ \\
\hline $\mathrm{O}$ & $1931(7)$ & $1279(4)$ & $1638(4)$ & $2.72(0.17)$ \\
\hline$N(1)$ & $2290(8)$ & $-627(4)$ & $948(5)$ & $2.11(0.19)$ \\
\hline$N(2)$ & $1062(10)$ & -3185 & $-646(6)$ & $3.19(0.23)$ \\
\hline $\mathrm{C}(1)$ & $2436(11)$ & $-118(5)$ & $237(6)$ & $2.41(0.24)$ \\
\hline $\mathrm{C}(2)$ & $1765(12)$ & $-304(6)$ & $-697(6)$ & $2.70(0.25)$ \\
\hline$C(3)$ & $1970(11)$ & $178(6)$ & $-1402(7)$ & $3.05(0.28)$ \\
\hline$C(4)$ & $2846(12)$ & $873(6)$ & $-1219(7)$ & $3.07(0.28)$ \\
\hline $\mathrm{C}(5)$ & 3477 (11) & $1093(6)$ & $-311(7)$ & $2.83(0.27)$ \\
\hline$C(6)$ & 3244 (11) & $604(5)$ & $405(6)$ & $2.44(0.25)$ \\
\hline$C(7)$ & $3347(10)$ & $-563(5)$ & $1827(6)$ & $2.31(0.24)$ \\
\hline $\mathrm{C}(8)$ & $3676(12)$ & $-1210(6)$ & $2402(6)$ & $2.74(0.26)$ \\
\hline$C(9)$ & $4811(12)$ & $-1135(6)$ & $3261(7)$ & $2.86(0.27)$ \\
\hline $\mathrm{C}(10)$ & $5596(12)$ & $-455(6)$ & $3564(7)$ & $3.39(0.29)$ \\
\hline$C(11)$ & $5264(12)$ & $193(6)$ & $2996(7)$ & $3.02(0.27)$ \\
\hline $\mathrm{C}(12)$ & $4138(10)$ & $141(5)$ & $2138(6)$ & $2.34(0.23)$ \\
\hline$C(13)$ & $1169(10)$ & $-1303(5)$ & $723(6)$ & $2.40(0.23)$ \\
\hline$C(14)$ & $1914(10)$ & $-1996(5)$ & $327(6)$ & $2.36(0.23)$ \\
\hline$C(15)$ & $488(11)$ & $-2555(6)$ & $-96(7)$ & $2.87(0.26)$ \\
\hline$C(16)$ & $-400(16)$ & $-3612(8)$ & $-1210(9)$ & $5.54(0.41)$ \\
\hline$C(17)$ & $2245(14)$ & $-3734(7)$ & $-44(9)$ & $4.37(0.36)$ \\
\hline
\end{tabular}

\section{Results and Discussion}

Syntheses of the Complexes The $\mathrm{HCl}$ salts of phenothiazine-5-oxide derivatives $(\mathrm{L})$ were allowed to react in ethanol at room temperature with metal (M) chloride $(\mathrm{M}=\mathrm{Co}(\mathrm{II}), \mathrm{Cu}(\mathrm{II}))$ to afford $1: 1$ complexes in almost quantitative yield according to the following equation,

$$
\mathrm{M}(\mathrm{II}) \mathrm{Cl}_{2}+\mathrm{LH}^{+} \mathrm{Cl}^{-} \rightarrow\left[\mathrm{MCl}_{3} \mathrm{LH}\right]
$$

where $\mathrm{L}=\mathrm{cpz}(\mathrm{O}), \operatorname{pmz}(\mathrm{O}), \operatorname{pmt}(\mathrm{O})$, and $\mathrm{cfz}(\mathrm{O})$ for $\mathrm{M}=\mathrm{Co}$, and $\mathrm{L}=\operatorname{cpz}(\mathrm{O})$ for $\mathrm{M}=\mathrm{Cu}$. The elementary analyses of the complexes obtained in this way are shown in Table IV. The crystals of the complexes are stable in air and the color is bright blue for all the cobalt(II) complexes and reddish brown for the copper(II) complex. Use of the ligand itself, instead of the $\mathrm{HCl}$ salt of the ligand, altered the reaction, and the above coordination complex was not obtained in every case.

Strutures of $\left[\mathrm{CoCl}_{3} \mathrm{cpz}(\mathrm{O}) \mathrm{H}\right](1)$ and $\left[\mathrm{CuCl}_{3} \mathrm{cpz}(\mathrm{O}) \mathrm{H}\right]$ (2) In spite of the different metals involved, the values of the crystallographic parameters of $\mathbf{1}$ and $\mathbf{2}$ are very close (see Table I). The configuration around the metal (M) coordinated by the three chlorine atoms and the oxygen atom adopts a tetrahedral geometry for both complexes as illustrated by the ORTEP diagram of the cobalt complex (Fig. 1). This figure also shows the atom numberings and the indications of the planes. In the tricyclic system, the two fused benzene rings of I and II are highly planar. The middle thiazine ring is folded around the axis of the $\mathrm{S}$ and $\mathrm{N}(1)$, the dihedral angles between the planes of III and IV being $147.8(4)$ and $146.0(5)^{\circ}$ for 1 and 2 , respectively. The $\mathrm{Cl}(4)$ atom occurs in a ratio of $80 \%$ compared with $20 \%$ for the $\mathrm{Cl}\left(4^{\prime}\right)$ atom, on account of the packing disorder in the crystals. The side-chain on the 10 -position projects in 
TABle IV. Analytical, Characteristic IR, and Magnetic Susceptibility Data

\begin{tabular}{|c|c|c|c|c|c|c|c|c|c|c|c|}
\hline & \multirow{3}{*}{ Molecular formula } & \multicolumn{6}{|c|}{ Analysis (\%) } & \multirow{3}{*}{$\begin{array}{c}v(\mathrm{~S}=\mathrm{O}) \\
\left(\mathrm{cm}^{-1}\right)\end{array}$} & \multirow{3}{*}{$\begin{array}{c}\Delta v \\
\left(\mathrm{~cm}^{-1}\right)\end{array}$} & \multirow{3}{*}{$\begin{array}{c}10^{6} \chi_{\mathrm{g}} \\
\left(\mathrm{cm}^{3} \mathrm{~g}^{-1}\right)\end{array}$} & \multirow{3}{*}{$\begin{array}{l}\mu_{\text {eff }} \\
\text { BM }\end{array}$} \\
\hline & & \multicolumn{3}{|c|}{ Found } & \multicolumn{3}{|c|}{ Calcd } & & & & \\
\hline & & $\mathrm{C}$ & $\mathrm{H}$ & $\mathrm{N}$ & $\mathrm{C}$ & $\mathrm{H}$ & $\mathrm{N}$ & & & & \\
\hline$\left[\mathrm{CoCl}_{3} \mathrm{cpz}(\mathrm{O}) \mathrm{H}\right]$ & $\mathrm{C}_{17} \mathrm{H}_{20} \mathrm{Cl}_{4} \mathrm{CoN}_{2} \mathrm{OS}$ & 40.53 & 4.07 & 5.35 & 40.74 & 4.02 & 5.59 & 917 & -80 & 18.1 & 4.54 \\
\hline$\left[\mathrm{CoCl}_{3} \mathrm{pmz}(\mathrm{O}) \mathrm{H}\right]$ & $\mathrm{C}_{17} \mathrm{H}_{21} \mathrm{Cl}_{3} \mathrm{CoN}_{2} \mathrm{OS}$ & 43.92 & 4.61 & 5.93 & 43.75 & 4.54 & 6.00 & 910 & -88 & 19.1 & 4.50 \\
\hline$\left[\mathrm{CoCl}_{3} \mathrm{pmt}(\mathrm{Q}) \mathrm{H}\right]$ & $\mathrm{C}_{17} \mathrm{H}_{21} \mathrm{Cl}_{3} \mathrm{CoN}_{2} \mathrm{OS}$ & 43.45 & 4.54 & 5.82 & 43.75 & 4.54 & 6.00 & 892 & -125 & 19.3 & 4.52 \\
\hline$\left[\mathrm{CoCl}_{3} \mathrm{cfz}(\mathrm{O}) \mathrm{H}\right]$ & $\mathrm{C}_{16} \mathrm{H}_{18} \mathrm{Cl}_{4} \mathrm{CoN}_{2} \mathrm{OS}$ & 39.84 & 4.10 & 5.13 & 39.45 & 3.72 & 5.75 & 925 & -87 & 16.6 & 4.28 \\
\hline$\left[\mathrm{CuCl}_{3} \mathrm{cpz}(\mathrm{O}) \mathrm{H}\right]$ & $\mathrm{C}_{17} \mathrm{H}_{20} \mathrm{Cl}_{4} \mathrm{CuN}_{2} \mathrm{OS}$ & 40.09 & 3.95 & 5.52 & 40.37 & 3.99 & 5.54 & 905 & -92 & 2.61 & 1.94 \\
\hline
\end{tabular}

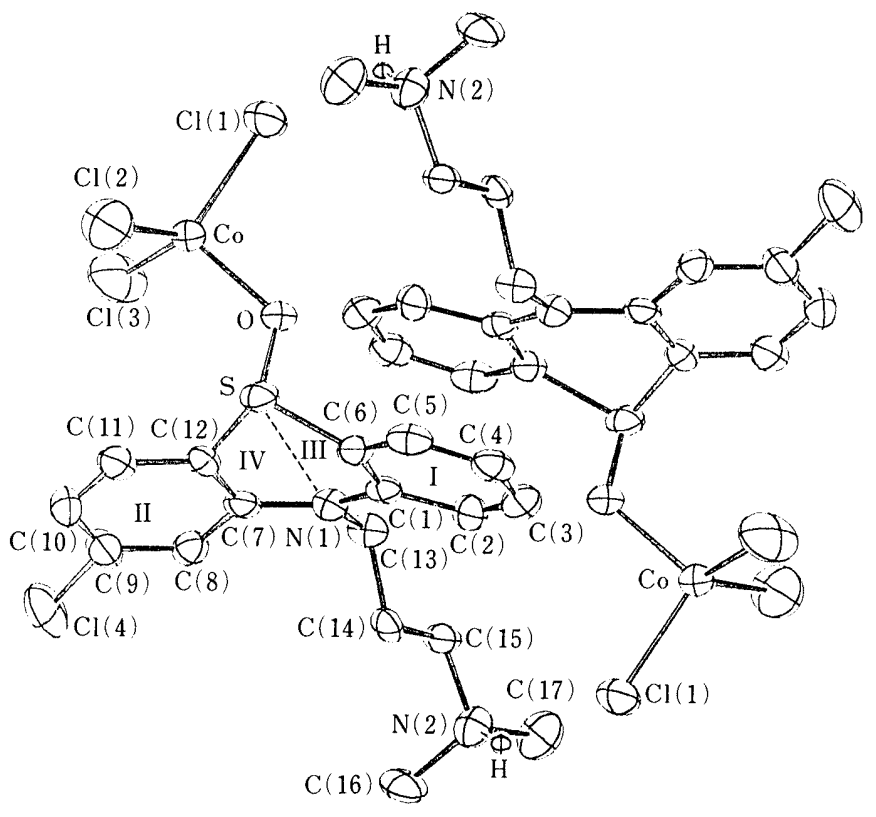

Fig. 1. The Dimer Structure of $\left[\mathrm{CoCl}_{3} \mathrm{cpz}(\mathrm{O}) \mathrm{H}\right](\mathbf{1})$ as Shown by the ORTEP Diagram with the Thermal Ellipsoids of the $50 \%$ Probability Level

The numbers I to IV are indications of the planes. The hydrogen atom attached to $\mathrm{N}(2)$ is located by calculation.

the opposite direction to that of the $\mathrm{Cl}_{3} \mathrm{MO}$ moiety. The selected bond lengths and angles are listed in Table $\mathrm{V}$ along with some non-bonded atomic distances.

Although the bond lengths and angles of the tricyclic systems and the side-chains were found to be quite similar for 1 and 2, the geometries around the metals are somewhat different, as is illustrated in Fig. 2. The bond angles of $\mathrm{Cl}-\mathrm{M}-\mathrm{Cl}$ and $\mathrm{Cl}-\mathrm{M}-\mathrm{O}$ range from 102.0 to $115.5^{\circ}$ for $\mathbf{1}$ and from 96.5 to $130.8^{\circ}$ for 2 , suggesting there is greater distortion of the copper complex from a tetrahedral form. The average length of $2.254 \AA$ for the $\mathrm{M}-\mathrm{Cl}$ bonds of $\mathbf{1}$ is a little longer than that of $2.218 \AA$ for 2 , the same trend being seen in the case of the $\mathrm{M}-\mathrm{O}$ bond length. This fact may be due to the larger ionic radius of a $\mathrm{Co}$ (II) ion than of a $\mathrm{Cu}$ (II) ion. The strengths of the $\mathrm{M}-\mathrm{O}$ bonds are approximately predictable from the wave numbers of the $\mathrm{S}=\mathrm{O}$ stretching vibration $\left(v_{\mathrm{S}=\mathrm{O}}\right)$ in the infrared spectra (Table IV). Complexation reduces the value of $v_{\mathrm{S}=0}$ by $80-125 \mathrm{~cm}^{-1}$ in comparison with the $v_{\mathrm{S}=\mathrm{o}}$ of the correspondin free ligand. The complexation shift is defined as $\Delta v=v_{\mathrm{S}=\mathrm{O}}($ complex $)-v_{\mathrm{S}=\mathrm{o}}$ (free ligand). The presence of the $\mathrm{Cl}$ atom in the 2-position of the ring seems to decrease the $-\Delta v$ values compared with the ligands with the same
TABLE V. Selected Bond Lengths $(\AA)$ and Angles $\left({ }^{\circ}\right)$

\begin{tabular}{lllr}
\hline \multicolumn{2}{c}{$\left[\mathrm{CoCl}_{3} \mathrm{cpz}(\mathrm{O}) \mathrm{H}\right]$} & \multicolumn{2}{c}{$\left[\mathrm{CuCl}_{3} \mathrm{cpz}(\mathrm{O}) \mathrm{H}\right]$} \\
\hline $\mathrm{Co}-\mathrm{Cl}(1)$ & $2.280(3)$ & $\mathrm{Cu}-\mathrm{Cl}(1)$ & $2.259(3)$ \\
$\mathrm{Co}-\mathrm{Cl}(2)$ & $2.237(3)$ & $\mathrm{Cu}-\mathrm{Cl}(2)$ & $2.200(3)$ \\
$\mathrm{Co}-\mathrm{Cl}(3)$ & $2.245(3)$ & $\mathrm{Cu}-\mathrm{Cl}(3)$ & $2.195(4)$ \\
$\mathrm{Co}-\mathrm{O}$ & $1.998(4)$ & $\mathrm{Cu}-\mathrm{O}$ & $2.006(7)$ \\
$\mathrm{S}-\mathrm{O}$ & $1.544(5)$ & $\mathrm{S}-\mathrm{O}$ & $1.548(7)$ \\
$\mathrm{Cl}(1)-\mathrm{Co}-\mathrm{Cl}(2)$ & $115.5(1)$ & $\mathrm{Cl}(1)-\mathrm{Cu}-\mathrm{Cl}(2)$ & $130.8(1)$ \\
$\mathrm{Cl}(1)-\mathrm{Co}-\mathrm{Cl}(3)$ & $109.3(1)$ & $\mathrm{Cl}(1)-\mathrm{Cu}-\mathrm{Cl}(3)$ & $103.8(1)$ \\
$\mathrm{Cl}(1)-\mathrm{Co}-\mathrm{O}$ & $102.0(2)$ & $\mathrm{Cl}(1)-\mathrm{Cu}-\mathrm{O}$ & $96.5(2)$ \\
$\mathrm{Cl}(2) \mathrm{Co}-\mathrm{Cl}(3)$ & $113.8(1)$ & $\mathrm{Cl}(2)-\mathrm{Cu}-\mathrm{Cl}(3)$ & $104.7(1)$ \\
$\mathrm{Cl}(2)-\mathrm{Co}-\mathrm{O}$ & $102.9(2)$ & $\mathrm{Cl}(2)-\mathrm{Cu}-\mathrm{O}$ & $97.7(2)$ \\
$\mathrm{Cl}(3)-\mathrm{Co}-\mathrm{O}$ & $112.7(2)$ & $\mathrm{Cl}(3)-\mathrm{Cu}-\mathrm{O}$ & $126.4(2)$ \\
$\mathrm{Co}-\mathrm{O}-\mathrm{S}$ & $122.7(3)$ & $\mathrm{Cu}-\mathrm{O}-\mathrm{S}$ & $121.2(3)$ \\
$\mathrm{C}(15)-\mathrm{N}(2)-\mathrm{C}(16)$ & $111.6(5)$ & $\mathrm{C}(15)-\mathrm{N}(2)-\mathrm{C}(16)$ & $110.8(8)$ \\
$\mathrm{C}(15)-\mathrm{N}(2)-\mathrm{C}(17)$ & $110.5(6)$ & $\mathrm{C}(15)-\mathrm{N}(2)-\mathrm{C}(17)$ & $111.9(8)$ \\
$\mathrm{C}(16)-\mathrm{N}(2)-\mathrm{C}(17)$ & $109.3(6)$ & $\mathrm{C}(16)-\mathrm{N}(2)-\mathrm{C}(17)$ & $110.4(9)$ \\
$\mathrm{Co} \cdots-\mathrm{N}(2)(x, y, z)$ & $9.724(6)$ & $\mathrm{Cu} \cdots \mathrm{N}(2)(x, y, z)$ & $9.615(9)$ \\
$\mathrm{Cl}(1) \cdots \mathrm{N}(2)$ & $3.240(6)$ & $\mathrm{Cl}(1) \cdots \mathrm{N}(2)$ & $3.269(9)$ \\
\multicolumn{3}{c}{$(-x,-y,-z)$} & \multicolumn{3}{c}{$(-x,-y,-z)$} \\
\hline
\end{tabular}

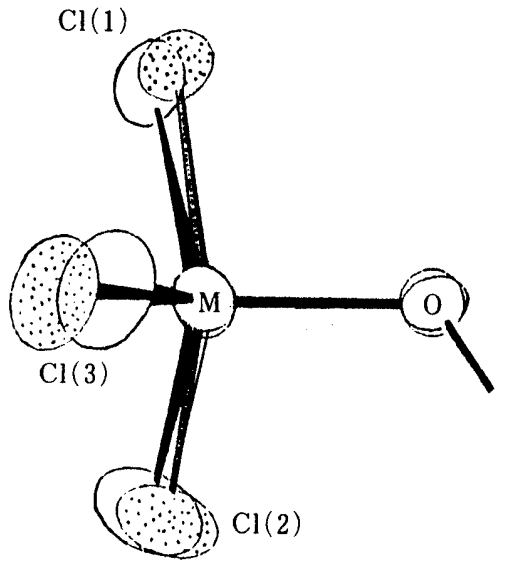

Fig. 2. The Comparative ORTEP Diagram around the Metals with the Thermal Ellipsoids of the $50 \%$ Probability Level

The $\mathrm{M}, \mathrm{O}$, and two $\mathrm{Cl}(3)$ atoms are in a plane with the $\mathrm{M}-\mathrm{O}$ bonds superposed The open ellipsoids represent the $\mathrm{Cl}$ atoms in $\left[\mathrm{CoCl}_{3} \mathrm{cpz}(\mathrm{O}) \mathrm{H}\right](1)$ and the dotted ones those in $\left[\mathrm{CuCl}_{3} \mathrm{cpz}(\mathrm{O}) \mathrm{H}\right](\mathbf{2})$

length of side-chain in the 10-position, owing to the reduced electron donation from the ring to the metal. This may result in a weakened $\mathrm{M}-\mathrm{O}$ bond by $\mathrm{Cl}$ substitution.

Table IV also lists the data for the magnetic susceptibilities of the complexes. The effective magnetic moments $\left(\mu_{\mathrm{eff}}\right)$ are corrected for the diamagnetism of the constituent atoms using Pascal's costants. The four cobalt complexes, $\left[\mathrm{CoCl}_{3} \mathrm{LH}\right]$, exhibit almost the same values of $\mu_{\text {eff }}(293 \mathrm{~K})$ which are comparable with $4.71 \mathrm{BM}$ of $(\mathrm{pyH})_{2}[\mathrm{Co}(\mathrm{II})-$ 
$\left.\mathrm{Cl}_{4}\right],{ }^{14}$ ) suggesting that the Co atoms of the present complexes are in their divalent state. As for the copper complex, its $\mu_{\text {eff }}$ value was observed to be $1.94 \mathrm{BM}$ at $293.5 \mathrm{~K}$ which is very close to the theoretical value of a divalent mononuclear copper complex. These facts indicate the presence of a negative charge around the $\mathrm{MCl}_{3} \mathrm{O}=\mathrm{S}$ moiety for both complexes. Meanwhile, the configuration around the $N(2)$ atom in the side-chain was found to be tetrahedral for the quaternary nitrogen because of the relatively large values of the $\mathrm{C}-\mathrm{N}(2)-\mathrm{C}$ angles, i.e., $109.3-$ $111.6^{\circ}$ for 1 and $110.4-111.9^{\circ}$ for 2 . The angles of the tertiary nitrogen are, in general, known to be less value than the tetrahedral angle of $109.5^{\circ}$ as a consequence of the electrostatic repulsions between the bonding electrons and the unshared electron pair. This implies the existence of a proton attached to the $\mathrm{N}(2)$ atom, which could not be detected on the Fourier map. Therefore, the negative charge around the metal(II) center is counterbalanced by the positive one on the $\mathrm{N}(2)$ atom to result in zwitterionic characteristics.

The intramolecular separations between the charged portions (for example, the distances between the metal atom and the $\mathrm{N}(2)$ atom are 9.724(6) $\AA$ for 1 and 9.615(9) $\AA$ for 2) are too large to expect electrostatic interactions between both charged sites in crystals. The remarkable features of the zwitterionic structures are directly reflected in the packing behavior of the molecules. The two molecules are stacked, overlapping each other, in a head-to-tail manner with the positively and negatively charged moieties arranged so as to make a dimer with a center of point symmetry, as shown in Fig. 1. The distances between the $\mathrm{N}(2)$ atom and the $\mathrm{Cl}(1)$ atom (symmetry operation: $-x$, $-y,-z)$ in the paired molecules were found to be $3.240(6)$ $\AA$ for 1 and $3.270(9) \AA$ for 2 . These values reveal the existence of a hydrogen bond ${ }^{15)}$ which stretches the $\mathrm{M}-\mathrm{Cl}(1)$ bond length by $c a$. $0.05 \AA$, compared with the other $\mathrm{M}-\mathrm{Cl}$ bond lengths. In the dimer skeleton, the major overlap in the paired molecules is seen in the tricyclic moieties which are found to lie almost parallel to each other with a separation of $c a$. $3.7 \AA$ for both cobalt and copper complexes.

To summarize, as far as the present cobalt(II) and
copper(II) complexes are concerned, it seems that the differences in the molecular and crystal structures are small despite the difference in the central metal atom. The slightly larger distortion from tetrahedral geometry for the copper complex may not merely be due to the requirements of the crystal packing, but may be mainly due to the JahnTeller effect of the $\mathrm{d}$ orbitals accommodating the nine electrons of $\mathrm{Cu}(\mathrm{II})$. In any event, it is interesting that both complexes, possessing a large and unsymmetrical ligand, are arranged so as to sustain as closely as possible a tetrahedral geometry around the divalent metal.

\section{References}

1) J. R. Holbrook, J. Neurochem., 60, 7 (1961); J. Harris, S. Gabay, "Biological Psychiatry Today," ed. by J. Obiols, C. Ballus, E. G. Monclus, J. Pujol, Elsevier, Inc., North-Holland, 1978, pp. 929932 , and references cites therein.

2) H. S. Gowda, Jayarama, J. Inorg. Nucl. Chem., 43, 2329 (1981); Jayarama, K. N. Thimmaiah, M. V. D'Souza, J. Indian Chem. Soc., 62, 418 (1985); B. Keshavan, J. Seetharamappa, ibid., 27A, 815 (1988); idem, Synth. React. Inorg. Met.-Org. Chem., 16, 979 (1986).

3) W. J. Geary, N. J. Mason, I. W. Nowell, L. A. Nixon, J. Chem. Soc., Dalton Trans., 1982, 1103; W. J. Geary, N. J. Mason, L. A. Nixon, I. W. Nowell, J. Chem. Soc. Chem. Commun., 1980, 1065.

4) N. P. Salzman, B. B. Brodie, J. Pharmacol. Exptl. Therap., 118, 46 (1956); N. P. Salzman, N. C. Moran, B. B. Brodie, Nature (London), 176, 46 (1955)

5) H. Alper, J. Q. Zhou, J. Org. Chem., 57, 3729 (1992).

6) C. T. Maxey, H. F. Sleiman, S. T. Massey, L. M. White, J. Am. Chem. Soc., 114, 5153 (1992); J. Bergman, J. Sidén, K. M. Moe, Tetrahedron, 40, 1607 (1984).

7) J. C. Zheng, R. J. Rousseau, S. Wang, Inorg. Chem., 31, 106 (1992).

8) W. Schindler, F. Hafliger, Helv. Chim. Acta, 37, 472 (1954).

9) R. B. Moffett, B. D. Aspergren, J. Am. Chem. Soc., 82, 1600 (1960).

10) G. M. Sheldrick, SHELX 86, Program for the solution of crystal structures, University of Göttingen, Germany, 1986.

11) T. Sakurai, K. Kobayashi, Rikagaku Kenkyusho Hokoku, 55, 69 (1978).

12) C. K. Johnson, ORTEP II, Report ORNL-3794, revised, Oak Ridge National Laboratory, Tennessee, 1971.

13) "International Tables for X-Ray Crystallography," Vol. 4, Kynoch Press, Birmingham, 1974.

14) R. S. Nyholm, Quart. Reviews, 7, 377 (1953).

15) G. C. Pimentel, A. L. McClellan, "The Hydrogen Bond," W. H. Freeman and Compary, San Francisco and London, 1960, p. 290. 